\title{
CULTURES
VIOLENCE
}

Racial violence and the origins of segregation in South Africa and the American South

IVAN EVANS 


\section{CULTURES OF VIOLENCE}

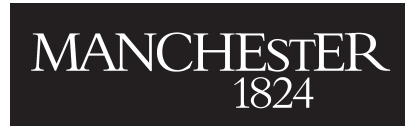

Manchester University Press 
Ivan Evans - 9781847792945

Downloaded from manchesterhive.com at 04/26/2023 09:06:33AM 


\section{CULTURES OF VIOLENCE}

\section{Lynching and racial killing in South Africa and the American South}

Ivan Evans

Manchester University Press

Manchester and New York

distributed in the United States exclusively by Palgrave Macmillan 
The right of Ivan Evans to be identified as the author of this work has been asserted by him in accordance with the Copyright, Designs and Patents Act 1988.

Published by Manchester University Press

Oxford Road, Manchester M13 9NR, UK

and Room 400, 175 Fifth Avenue, New York, NY 10010, USA

www.manchesteruniversitypress.co.uk

Distributed in the United States exclusively by

Palgrave Macmillan, 175 Fifth Avenue, New York,

NY 10010, USA

Distributed exclusively in Canada by

UBC Press, University of British Columbia, 2029 West Mall,

Vancouver, BC, Canada V6T 1 Z2

British Library Cataloguing-in-Publication Data

A catalogue record for this book is available from the British Library

Library of Congress Cataloging-in-Publication Data applied for

ISBN 9780719079047 hardback

First published 2009

$\begin{array}{llllllllllllllllllll}18 & 17 & 16 & 15 & 14 & 13 & 12 & 11 & 10 & 09 & 10 & 9 & 8 & 7 & 6 & 5 & 4 & 3 & 2 & 1\end{array}$

The publisher has no responsibility for the persistence or accuracy of URLs for any external or third-party internet websites referred to in this book, and does not guarantee that any content on such websites is, or will remain, accurate or appropriate.

Typeset by Special Edition Pre-press Services

www.special-edition.co.uk

Printed in Great Britain

by Cromwell Press Ltd, Trowbridge 